\title{
Reproductive Cycle and Fecundity in Natural Population of Edible Freshwater Crab, Oziothelphusa senex senex (Fabricius, 1798) (Decapoda: Brachyura)
}

Swetha $\mathrm{CH}^{1,2 \#}$, Girish $\mathrm{BP}^{1,2 \#}$ and Reddy $\mathrm{PS}^{1 *}$

${ }^{1}$ Department of Zoology, Sri Venkateswara University, Tirupati-517 502, India

${ }^{2}$ Department of Biotechnology, Sri Venkateswara University, Tirupati-517 502, India

\begin{abstract}
Rapid growth rate, high meat content, excellent palatability and resistance to white spot virus favored the culture of crab species in aquaculture industry. This study examined the natural reproductive cycle of edible fresh water crab Oziothelphusa senex senex by monthly measurement of ovarian index and histological examination of the gonads of the animals and determination of berried and young-one-bearing females collected monthly. The number of berried and young-one-bearing females was significantly higher in September-October. However, a small number of ovigerous and young-one bearing females were observed throughout the year. We also observed a breeding peak in September-October using ovarian index as marker. Within study catchments, mean number of eggs and young ones was 130 and 120 during September and 132 and 118 in October. The number of eggs spawned in the smallest ( $17 \mathrm{~g}$ body weight) crab is 80 and the largest ( $44 \mathrm{~g}$ body weight) crab is 140 . We also observed a positive correlation between the numbers of eggs spawned and body weight. Surprisingly, no correlation was found between the breeding cycle and the environmental factors such as temperature, photoperiod and rain fall. The lesser dependence on climatological factors for the completion of reproduction in the crab indicates greater potential of this species for crab fishery.
\end{abstract}

Keywords: Oziothelphusa senex senex; Gonad index; Histological examination; Reproductive cycle; Fecundity

\section{Introduction}

Oziothelphusa senex senex is a freshwater edible crab normally inhabiting in rice fields and irrigation canals throughout South India. Although originally restricted to freshwater, they can also survive in $100 \%$ seawater. The outbreak of white spot disease in South India and susceptibility of prawns to virus infection resulted in search for alternate species for aquaculture. In view of resistance to white spot virus, together with a rapid growth rate, high meat content and excellent palatability, the crab species was preferred for culture in recent years. Research on O. senex has concentrated on aspects pertaining to changes in physiology during thermal and salinity adaptation $[1,2]$. Aspects of endocrine control of glucose, nitrogen metabolism were also studied $[3,4]$. Besides, the crab was used as a tool to monitor environmental contamination [5-7]. Few aspects that have been left unexamined for this crab are its potential for aquaculture, development of artificial feed, and potential fecundity of the crab. The above information is very essential to attempt culture of this species.

Historically, studies involving reproductive biology of crustaceans have relied on description of ovarian development such as colour and weight of ovary $[8,9]$. Histological examination of ovaries was considered by several workers to determine the breeding cycles in several crustaceans [10]. Recording of egg-bearing females was used as index to determine the reproductive cycle of several organisms [1113]. Recently, determination of vitellogenin levels in circulation and in ovary was used as a sensitive tool to determine the reproductive stage in several crustaceans [14,15] including the crab Oziothelphusa [16]. Some aspects of the reproductive biology of $O$. senex (for example size at sexual maturity, colour and size of the ovary) have previously been examined [17]. Induction of ovarian maturation in this crab by leucineenkephalin and hydroxyprogesterone was also reported $[16,18,19]$. Reddy et al. [20] also reported the role of prostaglandins in inducing ovarian growth in this crab. Very little is known about the natural recruitment of crabs entering in to reproduction during different months. The aim of this study was to describe the reproductive biology of the crab, Oziothelphusa senex senex. Changes in gonad index and gonad histology were also monitored on a circannual basis.

\section{Material and Methods}

Adult Oziothelphusa senex senex were collected from rice fields and irrigation canals around Tirupati. Animals were collected every month during the years of 2011, 2012 and 2013. Only mature female crabs were selected for sampling. Number of egg bearing and young one bearing females were noted. Number and weight of eggs and young ones were noted from these crabs. Without allowing the remaining animals to acclimatize to laboratory conditions, their somatic weights were noted. The ovaries from 30 crabs per month were isolated, blotted on a filter paper and weighed to the nearest $\mathrm{mg}$ in an electronic balance. The ovarian index was calculated using the equation:

Ovarian index $(\mathrm{OI})=\mathrm{W}_{1} / \mathrm{W}_{2} \times 100$

where $\mathrm{W}_{1}$ is wet weight of the ovary and $\mathrm{W}_{2}$ is total wet weight of the crab.

Ovaries were assigned, on the basis of their macroscopic appearance, to one of the following five stages: 1) Immature; 2)

*Corresponding author: Sreenivasula Reddy, Department of Zoology, Sri Venkateswara University, Tirupati - 517 502, India, Tel: +91-0877-2249320, E-mail: psreddy1955@gmail.com; \#The authors wish it to be known that, in their opinion, the first two authors should be regarded as joint first authors

Received April 13, 2015; Accepted May 11, 2015; Published June 30, 2015

Citation: Swetha CH, Girish BP, Reddy PS (2015) Reproductive Cycle and Fecundity in Natural Population of Edible Freshwater Crab, Oziothelphusa senex senex (Fabricius, 1798) (Decapoda: Brachyura). J Aquac Res Development 6: 349. doi:10.4172/2155-9546.1000349

Copyright: @ 2015 Swetha $\mathrm{CH}$, et al. This is an open-access article distributed under the terms of the Creative Commons Attribution License, which permits unrestricted use, distribution, and reproduction in any medium, provided the original author and source are credited. 
developing (vitellogenic stage I); 3) mature (vitellogenic stage II); 4) ripe (vitellogenic stage III); and 5) spent. Ovaries from all females, were placed in Bouin's fixative (picric acid:formaldehyde:acetic acid, 75:25:5). After $24 \mathrm{~h}$, they were washed in water and dehydrated with ascending alcohol series. Dehydrated ovaries were embedded in paraffin wax after clearing in xylene, sectioned transversely at $6 \mu \mathrm{m}$ and stained with haematoxylin and counter stained with eosin. The maximum and minimum diameters of up to 50 randomly sectioned oocytes of each sectioned ovary were measured through the nucleus and the mean diameter was calculated. The proportions of oocytes at different stages of development in different months were also determined.

\section{Statistical analysis}

Statistical analysis was performed using SPSS 16.0 version. All
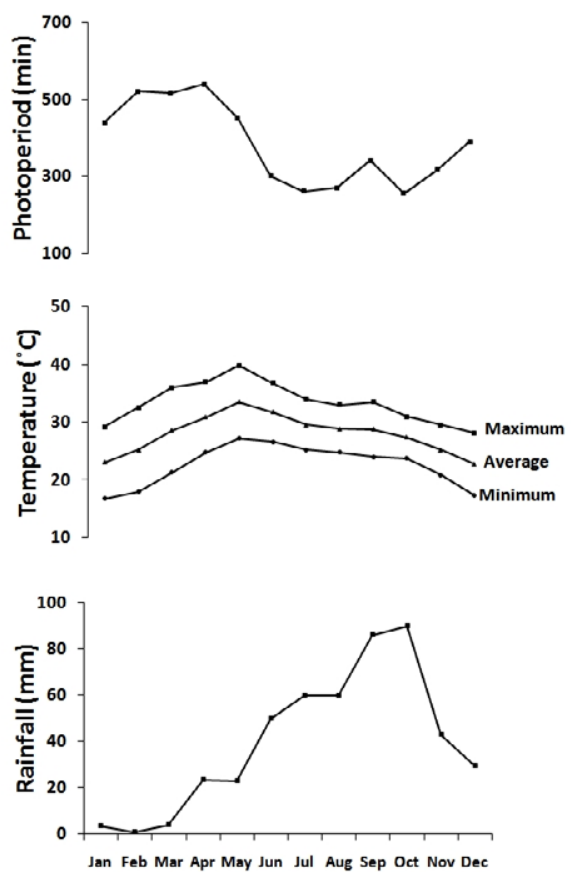

Figure 1: Recordings of monthly mean maxima and minima of temperature, photoperiod and rain fall in Tirupati (2011-2013). statistical tests are two-tailed and probability levels $<0.05$ was considered significant. Values are presented as mean \pm standard deviation.

\section{Results}

\section{Environmental variables of animal collection area}

Day lengths for the region declined progressively from maximum of 527 minutes in April to 251 minutes in October (Figure 1A). The temperature in the animal collection site varied between $25-40^{\circ} \mathrm{C}$. In summer months (April-June) the temperature was high $\left(>35^{\circ} \mathrm{C}\right)$ when compared to other months of the year $\left(<32.5^{\circ} \mathrm{C}\right)$ in three years studied (Figure 1B). The rain fall for the study area also showed a seasonal pattern typical of monsoon pattern (i.e., high monsoon and low nonmonsoon rainfall) (Figure 1C).

\section{Breeding periodicity}

The numerical incidence of egg-bearing and young-one-bearing crabs exhibited one breeding peak (Table 1). Maximum number of ovigerous and young-one-bearing animals was found (22\% and $20 \%$ respectively) in September. Berried and young-one bearing females were also present in other months of the year but less in number. The mean ovarian index of crabs ranges from 0.18 to 1.97 with a maximum value falling in the month of September (Figure 2). Since a small population of animals in vitellogenic stage was found year-round indicating the crabs can reproduce under any natural environmental conditions.

\section{Histological and macroscopic gonad descriptions}

The macroscopic appearance of female gonads at various developmental stages (Table 2) and their histological characteristics (Table 3) are summarized. The ovaries of crabs collected in September exhibited a typical breeding color in this month of the year. In January, February and March the ovaries are of creamy hue. In April to June the color is pale brown to light orange and in July to October, the color is bright orange. In the remaining months the ovaries appear white in color.

A close association was observed between the macroscopic appearance of ovaries at the various developmental stages and their histological characteristics. Ovaries that were in early developmental stages had greatest proportion of perinuclear oocytes with a size range of between 30-90 $\mu \mathrm{m}$ and a mean oocyte diameter was $53 \mu \mathrm{m}$; however similar size oocytes were also present in all other stages with different proportions (Figure 3A). Developing (early yolk vesicle) oocytes (90-

\begin{tabular}{|c|c|c|c|c|c|c|c|}
\hline Month & $\begin{array}{l}\% \text { of Egg bearing } \\
\text { crabs }(n=300)\end{array}$ & $\begin{array}{l}\% \text { of Young one } \\
\text { bearing crabs } \\
(n=300)\end{array}$ & $\begin{array}{c}\text { Number of eggs/ } \\
\text { crab }\end{array}$ & $\begin{array}{c}\text { Weight of egg } \\
(\mathrm{mg}) \\
(n=124)\end{array}$ & $\begin{array}{c}\text { Egg diameter } \\
\underset{(m m)}{(n=124)}\end{array}$ & $\begin{array}{c}\text { Number of young } \\
\text { ones/crab }\end{array}$ & $\begin{array}{l}\text { Weight of young } \\
\text { ones }(\mathrm{mg})(\mathrm{n}=106)\end{array}$ \\
\hline Jan & -- & 1 & -- & -- & -- & 95 & $11 \pm 0.12$ \\
\hline Feb & 2 & 2 & 106 & $8.5 \pm 0.15$ & $1.95 \pm 0.05$ & 98 & $11 \pm 0.23$ \\
\hline Mar & 5 & 4 & 110 & $10 \pm 0.12$ & $1.95 \pm 0.05$ & 102 & $11 \pm 0.21$ \\
\hline Apr & 6 & 9 & 107 & $10 \pm 0.14$ & $1.97 \pm 0.04$ & 97 & $12 \pm 0.24$ \\
\hline May & 9 & 7 & 105 & $9 \pm 0.16$ & $1.97 \pm 0.06$ & 96 & $12 \pm 0.18$ \\
\hline June & 4 & 7 & 110 & $9 \pm 0.20$ & $2.01 \pm 0.04$ & 108 & $12 \pm 0.19$ \\
\hline July & 5 & 4 & 106 & $9.5 \pm 0.16$ & $1.98 \pm 0.06$ & 100 & $11 \pm 0.21$ \\
\hline Aug & 5 & 4 & 99 & $10 \pm 0.21$ & $2.12 \pm 0.06$ & 108 & $12 \pm 0.22$ \\
\hline Sept & 22 & 20 & 130 & $10 \pm 0.22$ & $2.21 \pm 0.06$ & 120 & $13 \pm 0.21$ \\
\hline Oct & 18 & 19 & 132 & $11 \pm 0.19$ & $2.16 \pm 0.05$ & 118 & $13 \pm 0.18$ \\
\hline Nov & 10 & 8 & 122 & $10 \pm 0.18$ & $2.11 \pm 0.05$ & 120 & $12 \pm 0.19$ \\
\hline Dec & 1 & 4 & 120 & $10 \pm 0.22$ & $2.02 \pm 0.06$ & 116 & $12 \pm 0.14$ \\
\hline
\end{tabular}

Table 1: Monthly analysis of brood size and morphometric observations relation to egg bearing and young-one bearing female crabs. 
Citation: Swetha CH, Girish BP, Reddy PS (2015) Reproductive Cycle and Fecundity in Natural Population of Edible Freshwater Crab, Oziothelphusa senex senex (Fabricius, 1798) (Decapoda: Brachyura). J Aquac Res Development 6: 349. doi:10.4172/2155-9546.1000349

Page 3 of 6

\begin{tabular}{|l|l|}
\hline \multicolumn{1}{|c|}{ Ovarian stage } & \multicolumn{1}{c|}{ Macroscopic description } \\
\hline $\begin{array}{l}\text { I - Immature/recovering } \\
\text { (previtellogenic stage) }\end{array}$ & Ovaries are thin strand-like and translucent to opaque white; recovering spent ovaries in few crabs. \\
\hline $\begin{array}{l}\text { II - Developing (vitellogenic stage I) } \\
\text { III - Mature } \\
\text { (vitellogenic stage II) }\end{array}$ & Ovaries are thickened and dark yellow; oocytes are arranged compactly and are not clearly visible within the ovary. \\
\hline $\begin{array}{l}\text { IV - Ripe } \\
\text { (vitellogenic stage III) }\end{array}$ & Ovaries further thickened and orange in colour; oocytes are clearly visible in the ovary. \\
\hline V - Spent ovary & Ovaries swollen and large; dark brown or bright orange; oocytes are clearly visible in the ovary. \\
\hline
\end{tabular}

Table 2: The macroscopic description of the different stages of ovarian development in the crab $O$. senex sene.

\begin{tabular}{|c|c|c|}
\hline Ovarian stage & Histological description & Oocyte diameter $(\mu \mathrm{m})$ \\
\hline $\begin{array}{l}\text { I- Immature/recovering } \\
\text { (previtellogenic stage) }\end{array}$ & $\begin{array}{l}\text { Thick ovarian wall with centrally located germanium surrounded by number of oocytes; cells are } \\
\text { spherical or oval in shape and arranged at the periphery of oocytes; ovary consists of primary and } \\
\text { secondary oocytes; follicle cells are surrounded by bigger oocytes }\end{array}$ & $\begin{array}{c}30-90 \\
(53 \pm 9.2)\end{array}$ \\
\hline II - Developing (vitellogenic stage I) & $\begin{array}{l}\text { Oocytes consist of a band of yolk globules located peripherally with a prominent nucleus and } \\
\text { nucleolus; oocytes are enveloped by follicle cells. }\end{array}$ & $\begin{array}{c}90-120 \\
(110 \pm 8.8)\end{array}$ \\
\hline $\begin{array}{l}\text { III - Mature } \\
\text { (vitellogenic stage II) }\end{array}$ & Peripherally located yolk globules migrate towards the centre of oocytes. & $\begin{array}{c}120-170 \\
(162 \pm 11.1)\end{array}$ \\
\hline $\begin{array}{l}\text { IV - Ripe } \\
\text { (vitellogenic stage III) }\end{array}$ & $\begin{array}{l}\text { Large accumulation of yolk globules occupying the entire oocyte; disappearance of nucleus and } \\
\text { nucleolus; fine inter dispersed protein globules in between the large lipid yolk globules; appearance } \\
\text { of disintegrated follicle cells around oocytes. }\end{array}$ & $\begin{array}{c}170-210 \\
(198 \pm 8.9)\end{array}$ \\
\hline V - Spent ovary & Ovary shows several post-ovulatory follicles along with unextruted ova. Atretic oocytes also present. & $\begin{array}{l}50-100 \\
(71 \pm 12)\end{array}$ \\
\hline
\end{tabular}

Values in the parentheses are mean \pm S.D. ${ }^{*} n=12$ crabs (360 oocytes)

Table 3: Histological description and diameters of the oocytes of the different stages of ovarian development in the crab $O$. senex senex.

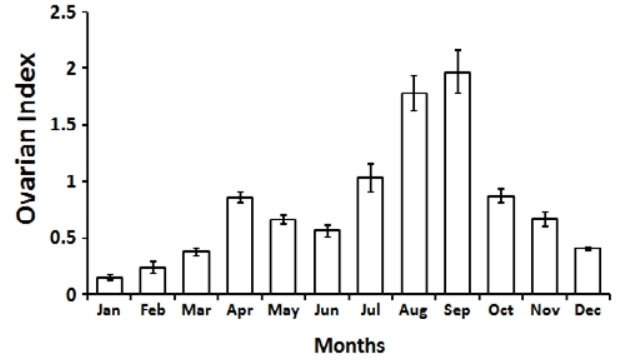

Figure 2: Monthly analysis of ovarian index of $O$. senex senex. Values are mean ( \pm S.D) of 30 crabs.

$120 \mu \mathrm{m})$ represented the greatest proportion of oocytes in stage II gonads, with a mean diameter of $110 \mu \mathrm{m}$ (Figure 3B). The oocytes were filled with protein yolk located peripherally with a thick ovarian wall and a prominent nucleus. Mature (late vitellogenic) oocytes had a size range of $120-170 \mu \mathrm{m}$ with a mean diameter of $162 \mu \mathrm{m}$ (Figure 3C). At this stage, the peripherally located yolk globules tend to migrate towards centre, gradually replacing the protein yolk. Ripe oocytes had a size range of $170-210 \mu \mathrm{m}$ with a mean of $198 \mu \mathrm{m}$. The cytoplasm of oocytes contains large accumulation of yolk globules occupying the whole oocyte (Figure 3D). Spent ovaries contained several degenerative oocytes, few late vitellogenic oocytes and many active follicle cells preparing the germanium for the next cycle of oogenesis (Table 3 and Figure $3 \mathrm{E}$ ). The majority of spent ovaries were in individuals that were berried with eggs ranging in diameter from 50 to $100 \mu \mathrm{m}$ (S.D \pm 12 $\mu \mathrm{m})$.

\section{Temporal descriptions of gonad development}

The mean oocyte diameter of different gonad stages of female Oziothelphusa senex senex was shown in Figure 4. The monthly proportions of different size oocytes in ovary of Oziothelphusa senex senex were presented in Figure 5. In the month of January, February

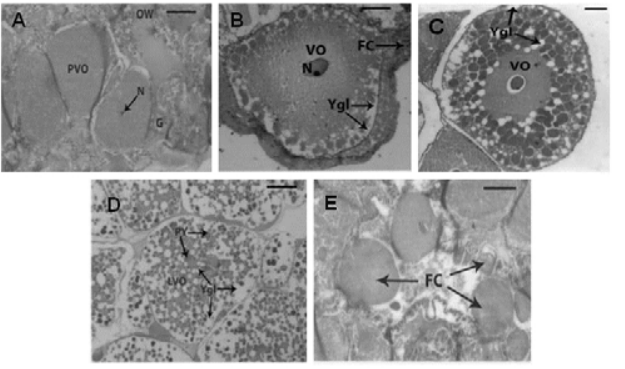

Figure 3: Microscopic appearance of the different gonadal developmental satges of female O. senex senex. A: Immature; B: Vitellogenesis Stage (developing); C: Vitellogenesis Stage II (mature); D: Vitellogenesis Stage III (ripe); E: Spent. N: Nucleus; FC: Follicle Cell; PVO: Previtellogenic Oocyte; VO: Vitellogenic Oocyte; LVO: Late Vitellogenic Oocyte; G: Germanium; OW: Ovarian Wall; YGL: Yolk Globule; PY: Protein Yolk.

and March the oocytes were in early development stages. The absence of vitellogenic oocytes is a characteristic feature in these months. The proportion of females with stage I ovaries was greatest in January with $90 \%$. In the months of April and May the oocyte diameter increases slightly and the yolk globules started accumulating at the periphery of the oocytes. Very few late vitellogenic oocytes were seen in these months. Larger oocytes were observed in the months of June and July. The oocytes contain large accumulation of yolk globules occupying the whole of oocyte. Ripe gonads (stage IV) were dominant in September, with $64 \%$ of females exhibiting this stage. The ovarian index in this month is at peak (Figure 2). In the months of October to December most of the ovaries were in spent condition. Several degenerate oocytes and few late vitellogenic oocytes were observed in these months. Appearance of vacuole in the ooplasm is a characteristic feature of degenerating or resorbing oocytes in the crabs in these months. This is in agreement with the decreased ovarian index during these months (Figure 2). Since a small population of animals in vitellogenic stage (I 


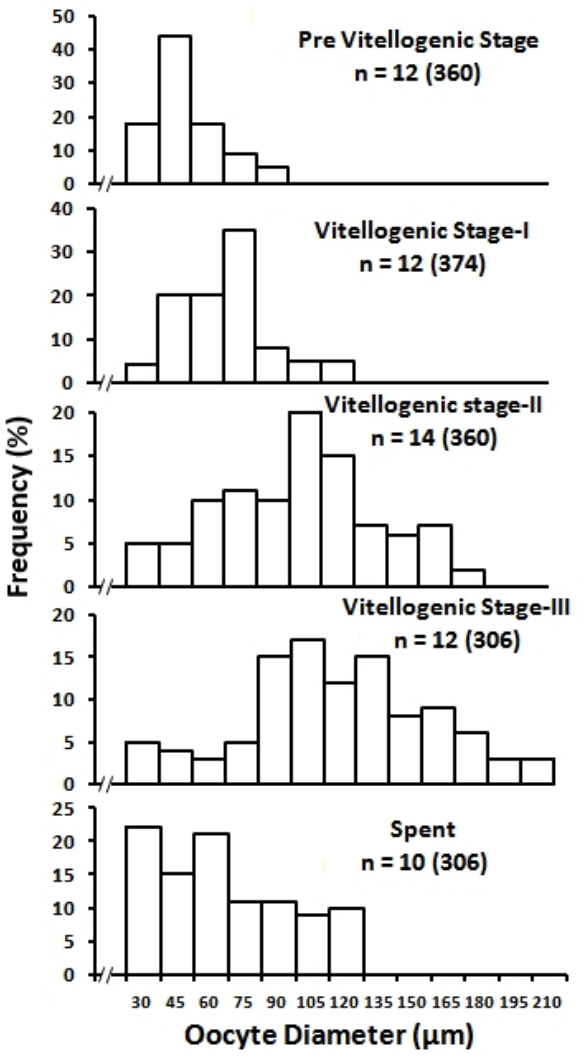

Figure 4: Mean oocyte diameters of the different gonad stages of female $O$. senex senex. $\mathrm{n}=$ Number of crabs (number of oocytes measured is in parentheses)

to III) was found year-round indicating the crabs can reproduce under any natural environmental conditions throughout the year.

Furthermore, monthly proportions of different ovarian stages mirrored the monthly proportions of egg-bearing and young-onebearing females. The percentage of mature females that were berried (egg bearing) increased from $5 \%$ in August to $22 \%, 18 \%, 10 \%$ in September, October and November respectively (Table 2).

\section{Relationship between body weight and fecundity}

The effective fecundity of female Oziothelphusa senex senex was represented by number of eggs in brood and ranged from 80 to 146 (Figure 6). The number of eggs spawned in the smallest crab (17 g body weight) is 80 and the largest crab ( $44 \mathrm{~g}$ body weight) is 146 (Figure $6)$. There was a positive correlation $\left(\mathrm{F}_{1,53}=3.791 ; \mathrm{p}<0.001\right)$ between effective fecundity and body weight of $O$. senex. The relationship between the effective fecundity and body weight of $O$. senex was best described by the equation: $\mathrm{EF}=56.43+1.80 \mathrm{BW}(\mathrm{r}=0.926)$, where $\mathrm{EF}$, effective fecundity; BW, body weight.

\section{Discussion}

\section{Seasonal breeding cycle}

The reproductive cycle, usually, includes a series of morphological, physiological, histological and metabolic events like gametogenesis, spawning, growth and development of egg [21]. These events are very useful to determine the scope and potentiality of the species for commercial exploitation. In decapods crustaceans, different reproductive end points were used to determine the reproductive stage of the organism. Recently, we have demonstrated that hepatopancreas but not the ovary is the site of vitellogenesis in female Oziothelphusa senex senex [22]. Further, we have reported that retinoid $\mathrm{X}$ receptor, ecdysteroid receptor and ecdysteroid responsive gene (E75) mRNA levels vary significantly during different vitellogenic stages in the crab, Oziothelphusa senex senex [23]. In the present study, ovarian maturation has been assessed using ovarian index, oocyte diameter,

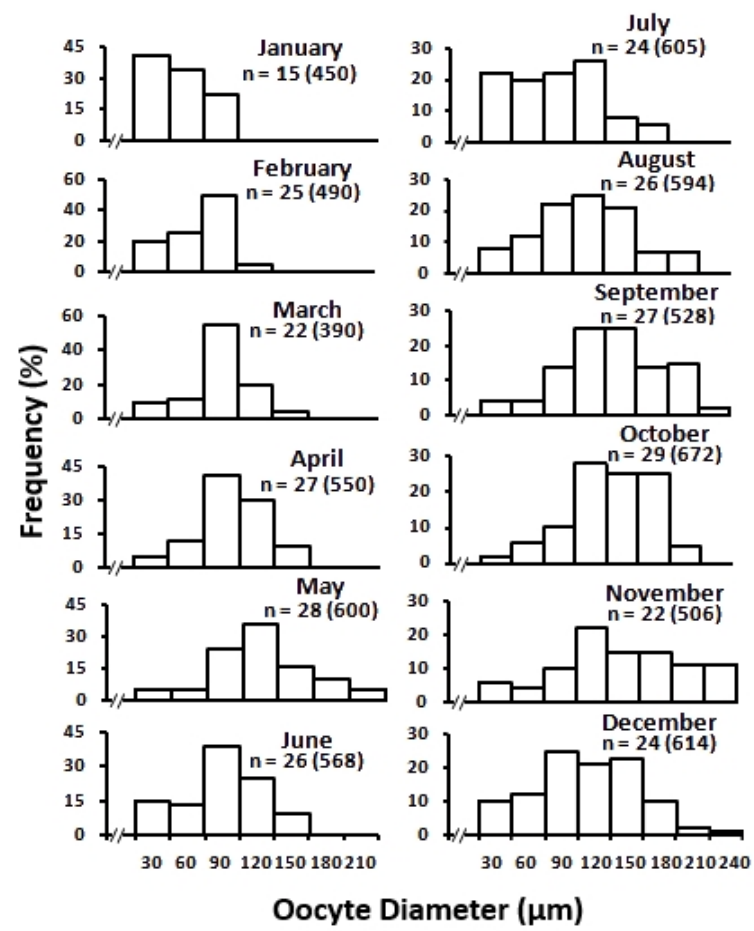

Figure 5: Monthly distributions of the diameters of oocytes in ovaries of $O$. senex senex. $n=$ Number of crabs (number of oocytes is in the parentheses).

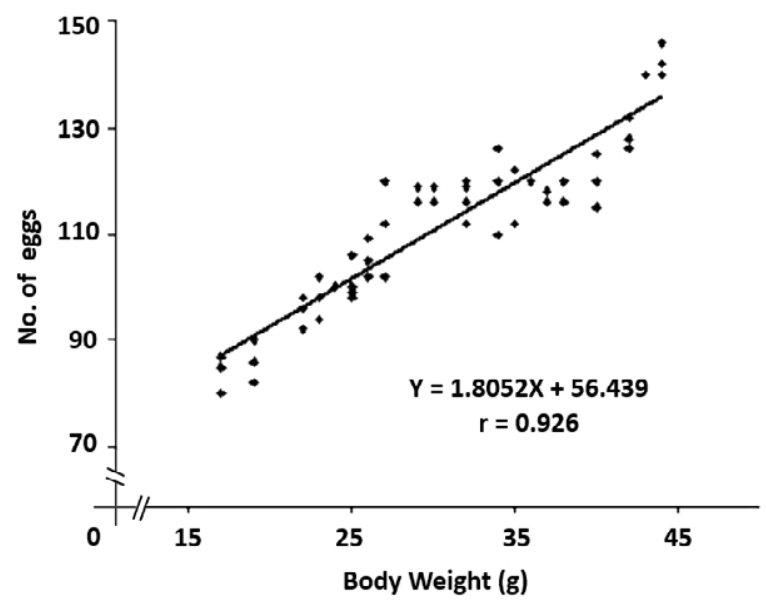

Figure 6: Regression analysis showing correlation between the body weight and the number of eggs freshly spawned. 
and histological alterations, and reproductive cycle has been judged based on incidences of egg-bearing and young-one-bearing animals in nature. The data indicate a significant breeding period as indicated by more number of females that were berried with eggs and young-ones falling in the colder part of the year (August-November). The above estimate of reproductive season was also supported by the trends in gonad stages in different months of the year. These trends in gonad development based on macro- and micro-scopic examination of gonads were mirrored in the trends of the ovarian indices.

The numerical incidence of berried females observed in the present study (maximum 22\% in September) is relatively low when compared to marine crustaceans. The marine crustaceans show consistently high percentage of females in berry in a catch during the breeding period. Boolootien et al. [24] reported $100 \%$ berried Hemigrapsus nudus, Petrolisthes cinctipes, 90\% berried Emerita analoga and 80\% berried Pachygrapsus crassipes in a catch during breeding season. Beatty et al. [8] also recorded higher spawning rates $(95.6 \%)$ for mature female crayfish Cherax cainii at Lake Navarino. The possible reason for the high incidence of berried females in a catch may be the marine habitat with the uniform and ideal environment will provide favorable breeding place for the organism for the complete breeding expression of the females of a population during breeding period.

In most crustaceans, the eggs are attached to the pleopods and the abdomen is held deflexed after the formation of the berry. In O. senex the eggs are not attached to the pleopods but are protected within the tightly inflexed abdomen making a brood. In O. senex egg diameter is relatively large $(>1.95 \mathrm{~mm}$ ) when compare to egg diameter of spiny lobster Palinurus homarus $(0.54 \mathrm{~mm})[25,26]$, mangrove crab Sesarma rectum $(0.611 \mathrm{~mm})$ [27] hermit crab Eupagurus bernhardus $(0.75 \mathrm{~mm})$ [28], and spider crab Mithraculus forceps $(0.56 \mathrm{~mm})$ [29]. Pillai [13] reported that in marine species, the number of eggs varies from 3,000 to $10,000,000$ per female and the size of each egg varies from 0.2 to 1.8 $\mathrm{mm}$. The number of eggs in fresh water crustaceans varied from 10 to 800 per female and the size of egg is between 0.5 to $2.8 \mathrm{~mm}$. Such differences in the number of eggs laid and in the size of eggs between the marine and fresh water forms may be explained by the nature of egg development and the survival rate of young ones. The marine and estuarine crustaceans that return to sea for breeding bear a large number of small yolky eggs [30]. The fresh water crab O. senex senex remain in fresh water for spawning bear less number of large yolky eggs. The difference in size and number of eggs laid by the marine and fresh water crustaceans is explained in terms of the nature of egg development as well as the survival rate of young ones [31]. In O. senex senex, the entire larval duration will be completed within the egg and the young ones (crab-lets) are retained in the brood of the female. In the crab, though the number of eggs spawned are less but the survival rate is relatively large $(>96 \%)$. The number of eggs present in the berry of $O$. senex increases as the body weight increases. Cobo and Okamori [29] observed strong correlation between fecundity and body size in spider crab Mithraculus forceps. Arshad et al. [32] showed a positive correlation between fecundity and different parameters like carapace length, carapace width and body weight in blue swimming crab Protunus pelagicus.

\section{Influence of environmental variables on reproduction}

A positive correlation between temperature and gonadal gravimetry is evident during summer, especially from January-May. During these months the average temperature rises from $23.36^{\circ} \mathrm{C}$ to $33.48^{\circ} \mathrm{C}$ and this rise is parallel by a gradual rise in ovarian index during these months. High temperature was found to hasten the growth and maturation of ovaries in different crustaceans. Temperature induced quick maturation was also observed in Cambarus shufeldti [33]. Habashy and Hassan [34] showed that optimum level of temperature i.e. $29^{\circ} \mathrm{C}$ is required for increased reproductive success in Macrobrachium rosenbergii. In $O$. senex senex, temperature as a gonad stimulating environmental factor is applicable only during the warmer part of the year, whereas this temperature correlation does not holds good with regard to the winter period peaking of ovarian gravimetry.

During winter, photoperiod shows a correlation with the ovarian index and maturation. Similar photoperiod associated gonad maturation was observed in Cambarus virilis [35], Procambarus simulans [36] and in Procambarus clarkii [37,38]. In Litopenaeus vannamei feeding activity, growth and survival of smaller animals were affected by photoperoid [39]. Further, studies of Tidwell et al. [40] indicated that continual light conditions have positive impact on survival of Macrobrachium rosenbergii juveniles during the nursery phase. In Homarus gammarus hatching of eggs also was found to be stimulated by long photoperiod [41]. Co-variation analysis carried out with regard to the number of eggs in the brood purse of berried females against the various physical factors (temperature: $r=0.0657$; photoperiod: $r=0.1495$; rainfall: $r=0.5759$ ) yielded only a small and insignificant correlation coefficients. It is precisely this freedom from physical factors like temperature and photoperiod that renders the breeding biology of Oziothelphusa senex senex pliable to manipulation. This freedom can be exploited in the development of aquaculture technology for this edible crab.

This study represents the first comprehensive study of reproductive biology of a wild population of Oziothelphusa senex senex and the first histologically based study on the reproductive biology of a freshwater edible crab. Lack of dependence on the climatological factors for the completion of reproductive cycle can be exploited in the development of aquaculture technology for this edible crab.

\section{Acknowledgement}

The authors thank Prof. K.V.S. Sarma, Department of Statistics, S.V. University, Tirupati for help in analyzing the data. The help of Mr. S. Umasankar Department of Biotechnology is acknowledged. The Staff members of Department of Biotechnology are appreciated for their assistance in the laboratory. $\mathrm{CH}$. Sweth and B. P. Girish acknowledge University Grants Commission (BSR-RFSMS) and Council of Scientific and Industrial Research (CSIR-JRF) respectively for awarding research fellowships. Part of this work was also funded by Department of Science and Technology, Department of Biotechnology and University Grants Commission New Delhi to PSR.

\section{References}

1. Ramamurthi $R$ (1966) Succinic dehydrogenase activity in a freshwater crab in relation to salinity stress. Comparative Biochemistry and Physiology 19: 645-648.

2. Krishnamoorthy RV, Srihari K (1973) Changes in excretory pattern of the freshwater field crab, Paratelphusa hydrodromous upon adaptation to higher salinities. Marine Biology 21: 341-348.

3. Raghavaiah K, Ramamurthi R, Chandrasekharam V, Scheer BT (1980) Neuroendocrine control of nitrogen metabolism in the Indian field crab, Oziotelphusa senex senex (Fabricius) I. End products and elimination. Comparative Biochemistry and Physiology 67: 433-445.

4. Reddy PS (1990) Neuroendocrine control of metabolism in the freshwater crab Oziotelphusa senex senex. J Crustacean Bio 10: 595-607.

5. Reddy PS, Bhagyalakshmi A, Ramamurthi R (1983) Effect of subletha concentration of sumithion on limb regeneration of freshwater crab (Oziotelphusa senex senex). Experientia 39: 1380-1381.

6. Reddy PS, Bhagyalakshmi A, Ramamurthi R (1985) Molt inhibition in the crab Oziotelphusa senex senex following exposure to malathion and methylparathion. Bulletin of Environmental Contamination and Toxicology 35 92-97. 
Citation: Swetha CH, Girish BP, Reddy PS (2015) Reproductive Cycle and Fecundity in Natural Population of Edible Freshwater Crab, Oziothelphusa senex senex (Fabricius, 1798) (Decapoda: Brachyura). J Aquac Res Development 6: 349. doi:10.4172/2155-9546.1000349

7. Reddy PS (1992) Molt inhibition in the crab Oziotelphusa senex senex in response to heavy metal toxicity. Pollution Research 11: 191-195.

8. Beatty SJ, Morgan DL, Gill HS (2003) Reproductive biology of the large freshwater crayfish, Cherax cainii in south-western Australia. Marine and Freshwater Research 54: 97-608.

9. Whitmore N, Huryn AD (1999) Life history and production of Paranephrops zealandicus in a forest stream, with comments about the sustainable harvest of a freshwater crayfish. Freshwater Biology 42: 467- 478.

10. Varadarajan S, Subramoniam T (1980) Histological changes during vitellogenesis in the ovary of the hermit crab Clibanarius clibanariusi. Proceedings of Indian National Science Academy 46: 645-651.

11. Jegla TC (1966) Reproductive and molting cycles in cave crayfish. Biological Bulletin 130: 345-358.

12. Knudson JW (1960) Reproduction life history and larval ecology of the California xanthidae the pebble crabs. Pacific Science: 14: 3-17.

13. Pillai BS (1960) Studies on the shrimp Caridina laevis II. Reproductive system. J Marine Biology Association of India 2: 226-236.

14. Tsukimura B (2001) Crustacean vitellogenesis: its role in oocyte development. American Zoologist 41: 465-476.

15. Wilder MN, Subramoniam T, Aida K (2002) Progress in vetellogenesis. Science Publishers Inc. Plymouth, United Kingdom.

16. Reddy PR, Kiranmayi P, Thanuja Kumari K, Reddy PS (2006) 17ahydroxyprogesterone induced ovarian growth and vitellogenesis in the freshwater rice field crab, Oziotelphusa senex senex. Aquaculture 254: 768775 .

17. Ramamurthi $R$, Raghupathi $M$, Chandrasekharam V, Jayasundaramma $B$ (1986) Observations on the breeding biology of the edible freshwater crab. Trends in Life Sciences 1: 67-76.

18. Kishori B, Reddy PS (2000) Antagonistic effects of opioid peptides in the regulation of ovarian growth of the Indian rice field crab, Oziotelphusa senex senex Fabricius. Invertebrate Reproduction and Development 37: 107-111.

19. Kishori B, Reddy PS (2004) Influence of leucine enkephalin on molting and vitellogenesis in the freshwater crab, Oziotelphusa senex senex Fabricius (1971) (Decapoda, Brachyura). Crustaceana 76: 1281-1290.

20. Reddy PS, Reddy PR, Nagaraju GPC (2004) The synthesis and effect of prostaglandins on the ovary of the crab Oziotelphusa senex senex. General and Comparative Endocrinology 135: 35-41.

21. Hartnoll RG (1963) The biology of Manx spider crabs. Proceedings of Zoological Society of London 141: 423-496.

22. Girish BP, Swetha CH, Reddy PS (2014) Hepatopancreas but not the ovary is the site of vitellogenesis in female fresh water crab, Oziothelphusa senex senex. Biochemical and Biophysical Research Communications 447: 323-327.

23. Girish BP, Swetha CH, Reddy PS (2015) Expression of RXR, EcR, E75 and VtG mRNA levels in the hepatopancreas and ovary of the freshwater edible crab, Oziothelphusa senex senex (Fabricius, 1798) during different vitellogenic stages. The Science of Nature 102: 20.

24. Boolootien RA, Giese AC, Farmanfarmian A, Tucker J (1959) Reproductive cycles of five west coast crabs. Physiological Zoology 32: 213-220.

25. Berry PF (1970) Mating behaviour, oviposition and fertilization in the spiny lobster, Panulirus homarus. Investigational Report. Oceanographic Research Institute 31: 1-27.

26. Berry PF (1971) The biology of the spiny lobster, Panulirus homarus of the east coast of Southern Africa. Investigational Report. Oceanographic Research Institute 28: 1-75.

27. Leme MHA (2004) Fecundity and fertility of the mangrove crab Sesarma rectum Randall, 1840 (Grapsoidea) from Ubatuba, São Paulo, Brazil. Nauplius 12: 39-44.
28. Pandian TJ, Schumann KH (1967) Chemical composition and calorific content of egg and zoea of the hermit crab, Eupagurus bernhardus. Helgolander Wiss Meeresunters 16: 225-230.

29. Cobo VJ, Okamori CM (2008) Fecundity of the spider crab Mithraculus forceps (Decapoda, Mithracidae) from the northeastern coast of the state of São Paulo, Brazil. Iheringia Sér. Zool. Porto Alegre, 98: 84-87.

30. Bliss DE (1968) Transition from water to land in decapod crustaceans American Zoologist 8: 355-392.

31. Steele DH, Steele VJ (1975) The biology of the Gammarus in the north western Atlantic. XI. Comparison and discussion. Canadian Journal of Zoology 53: 1116-1126.

32. Arshad A (2006) Study on fecundity, embryology and larval development of blue swimming crab, Portunus pelagicus (Linnaeus, 1758) under laboratory conditions Research J. Fisheries and Hydrobiology 1: 35-44.

33. Lowe ME (1961) The female reproductive cycle of the cray fish, Cambarus shufeldti : The influence of environmental factors. Tulane Studies in Zoology 8: 157-176.

34. Habashy MM, Hassan MMS (2010) Effects of temperature and salinity on growth and reproduction of the fresh water prawn, Macrobrachium rosenbergi (Crustacea-Decapoda) in Egypt. International Journal Environmental Science and Engineering 1:83-90.

35. Stephens GJ (1952) Mechanism regulating the reproductive cycle in the cray fish Cambarus. I. The female cycle. Physiological Zoology 25: 70-83.

36. Perryman EK (1969) Procambarus simulans : Light induced changes in neurosecretory cells and in ovarian cells. Transactions of the American Microscopical Society 88: 514-521.

37. Suko T (1956) Studies on the development of the cray fish. IV. The development of winter egg. The Science reports of the Saitana University Series BII: 213-219.

38. Suko T (1958) Studies on the development of the cray fish. V. The histological changes of the developmental ovaries influenced by the condition of darkness. The Science reports of the Saitana University Series BIII: 67-78.

39. Sanudin N, Tuzan AD, Seok Kian Yong A (2014) Feeding activity and growth performance of shrimp post larvae Litopenaeus vannamei under light and dark condition. Journal of Agricultural Science 6: 11.

40. Tidwell JH, Coyle S, Varanum A, Bright LA, McCathy M, etal. (2001) The effect of photoperiod on growth and survival of juvenile freshwater prawn Macrobrachium rosenbergii in nursery tanks. J Applied Aquaculture 11: 41-47.

41. Branford JR (1978) The influence of day length, temperature and season on the hatching rhythm of Homarus gammarus. Journal of Marine Biological Association of the United Kingdom 58: 639-658. 